\title{
Effect of intake Selenium supplementation on lipid profile and cardiorespiratory function in rest situation and subsequent an exercise session in active men
}

\author{
Khaled Salehi ${ }^{1}$, Fatah Moradi ${ }^{2}$ \\ ${ }^{1}$ Department of Physical Education and Sport Sciences, Saghez Branch, Islamic Azad University, Saghez, Iran \\ ${ }^{2}$ Corresponding author; Department of Physical Education and Sport Sciences, Saghez Branch, Islamic Azad University, Saghez, \\ Iran Tel: +988736244743 Fax:+988736244750 E-mail: moradifatah@yahoo.com
}

Citation Salehi K, Moradi F. [Effect of intake Selenium supplementation on lipid profile and
cardionespiratory function in rest situation and subsequent an exercise session in active men]. J Birjand Univ
Med Sci. 2019; 26(2): 137-46. [Persian]

\begin{abstract}
Background and Aim: Selenium is an essential mineral with antioxidant properties that play a role in metabolic processes, and its relationship with lipid profile has been shown in some studies. The purpose of this study was to investigate the effect of intake selenium supplementation on lipid profile and cardio-respiratory function in rest situation and subsequent an exercise session in active men.

Materials and Methods: The research method was quasi-experimental. In this study, 19 active men were selected from among soccer players in the city of Saghez and were randomly divided into two experimental (supplementation, $\mathrm{n}=10$ ) and control (placebo, $\mathrm{n}=9$ ) groups. The assessments were carried out in three stages (pre-taking the supplementation, after taking the supplementation, and immediately after an exercise session). General characteristics of subjects studied, cardio-respiratory function (aerobic power), and levels of lipid profile (triglyceride (TG), total cholesterol (TC), high-density lipoprotein (HDL), and low-density lipoprotein (LDL) were measured. Consumption period of supplement was a month. (A $200 \mu \mathrm{g}$ Selenium capsule per day). To analyze the data, onefactor analysis of variance with repeated measurements was used at a significant level of $\mathrm{P}<0.05$.
\end{abstract}

Results: Selenium supplementation increased cardio-respiratory function $(47.7 \pm 7.4 \mathrm{vs} .39 .7 \pm 8.0 \mathrm{ml} / \mathrm{kg} / \mathrm{min}, \mathrm{P}=0.017)$, while has no effect on resting and following exercise session levels of TG $(\mathrm{P}=0.258)$, TC $(\mathrm{P}=0.737)$, HDL $(\mathrm{P}=0.406)$, and $\mathrm{LDL}(\mathrm{P}=0.312)$.

Conclusion: Taking the selenium supplementation for one month does not seem to affect the components of the on lipid profile in rest situation and subsequent an exercise session, however, it can help improve the cardio-respiratory function of active men.

Keywords: Selenium; Aerobic Power; Lipid Profile; Men 


\title{
اثر مصرف مكمل سلنيوم بر نيمرخ جربى و عملكرد قلبى -تنفسى در وضعيت استراحت و متعاقب يك جلسه ورزش در مردان فعال
}

خالد صالحى 'Did)، فتاح مر ادى 'idi)

\begin{abstract}
جكيله

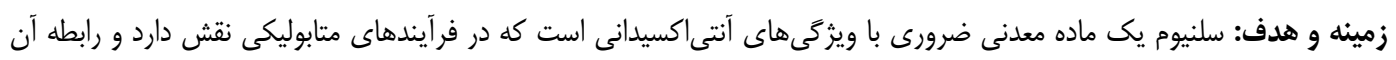

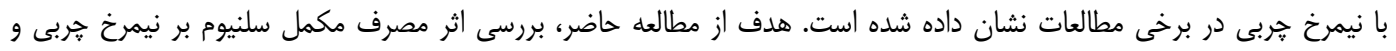

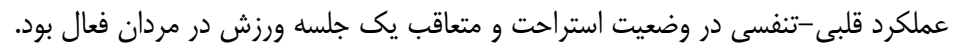

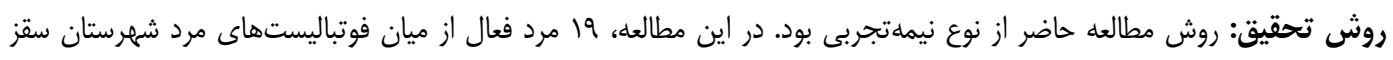

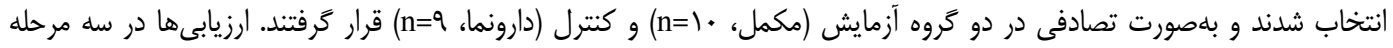

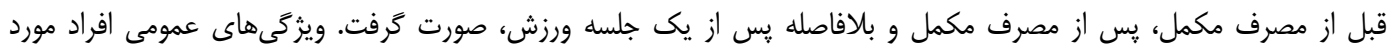

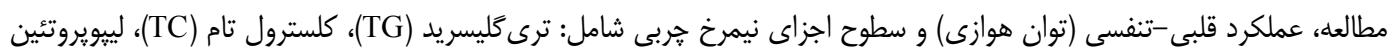

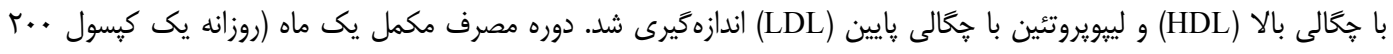

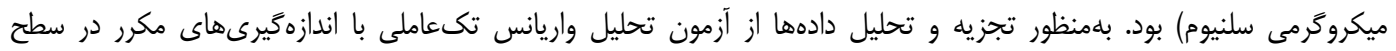

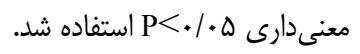

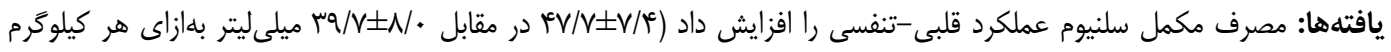

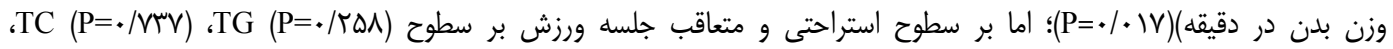

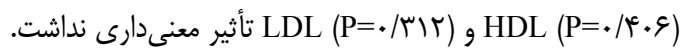

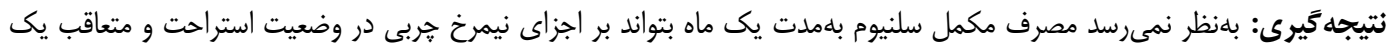

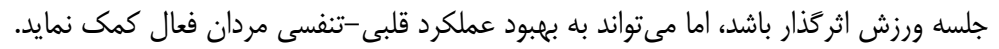
وازههاى كليدى: سلنيوم؛ توان هوازى؛ نيمرخ جربى؛ مردان

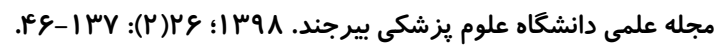
دريافت:
\end{abstract}


متابوليسم كلوكز - احتمالاً از طريق اعمال شبهانسولينى - مأل

إعمال كند كه مىتواند عوارض ديابت را به تأخير اندازد.

سلنيوم يك عنصر كمياب است و بر طبق دستورالعمل

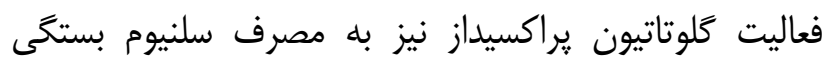

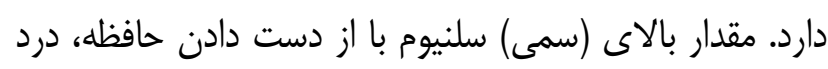

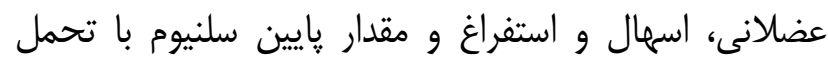
كلوكز آسيبديده و هيير گليسمى باردارى همراه است (1).

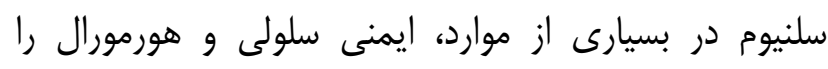

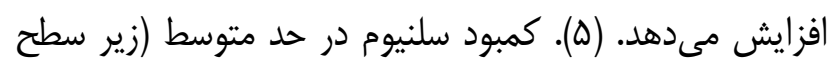

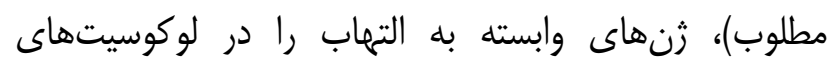

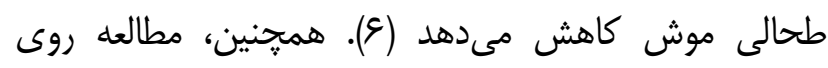
آزمودنىهايى كه داراى كمبود مشخص موش سلنيوم سرم بودند نشان داد متعاقب مصرف سلنيوم، افزايش سريعى در فعاليت

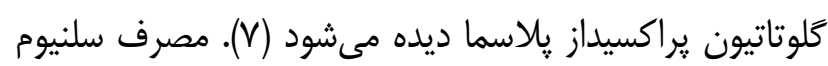
قابليت معنىدارى در كاهش فشار اكسايشى مرتبط با اضافه

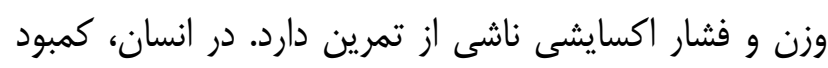

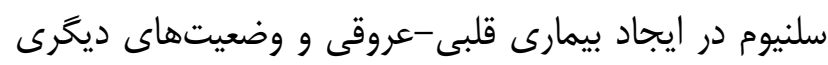

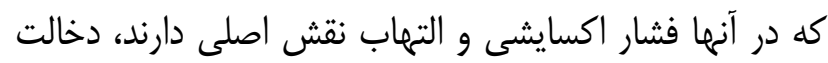

دارد (^).

نقش سلنيوم در ييشگيرى از بيمارىهاى مزمن، كانون توجه بحثهاى علمى در حال رشد و تحقيقات زيادى است.

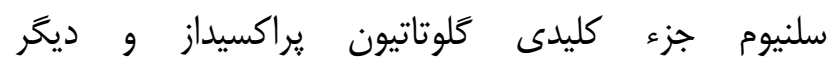
سلنويروتئينهاى دخيل در عملكردهاى آنزيمى ضرورى

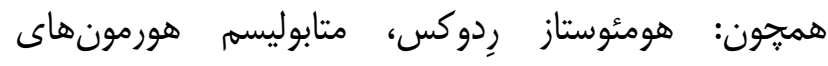

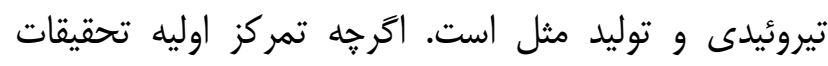

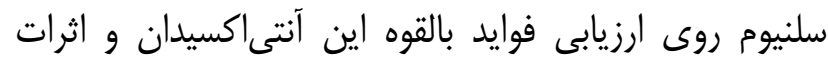

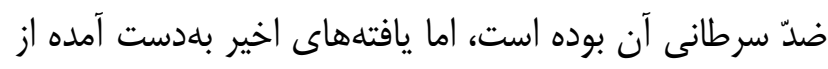

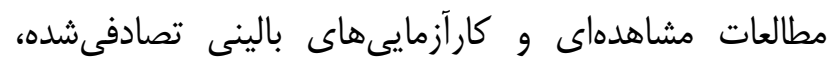

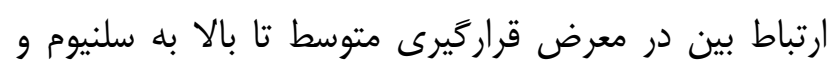

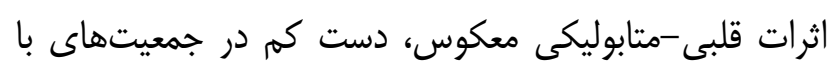
تغذيه خوب را نشان دادهاند (9). مصرف سلنيوم ممكن است آترواسكلروز، افزايش بيش از

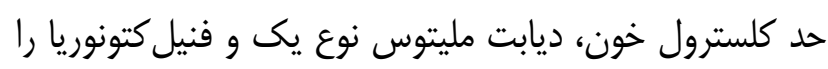

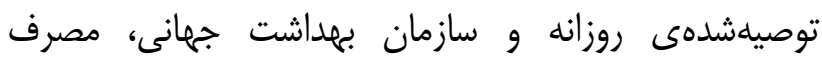

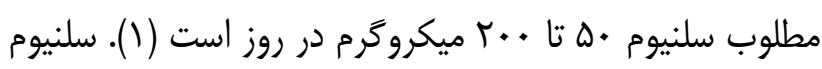

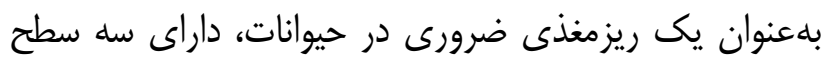

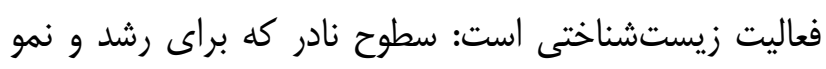

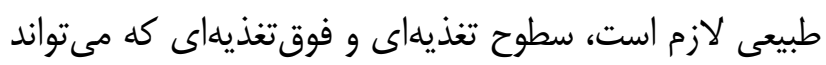
در بلن ذخيره گردد و عملكردهاى هومئوستازى را حفظ نمايد نايد

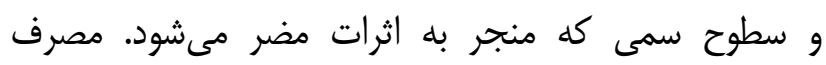

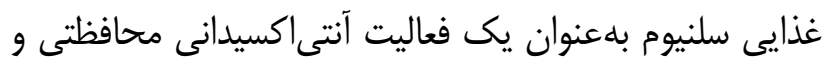
يك روش كاهش مرى و مير ناشى از بيمارىهاى حاد،

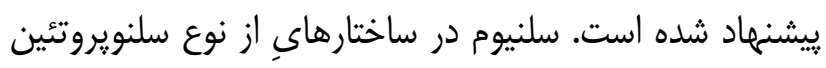

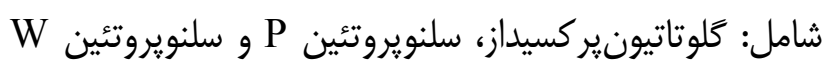
دخيل است. اين بروتئينها يك نقش محافظتى در برابر مواد

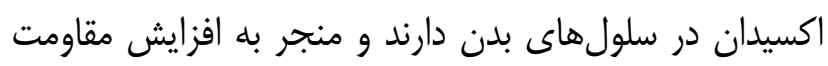

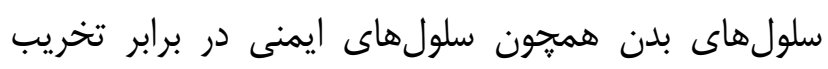

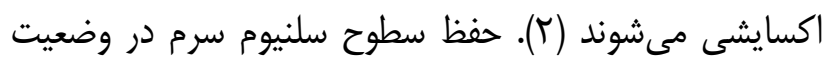

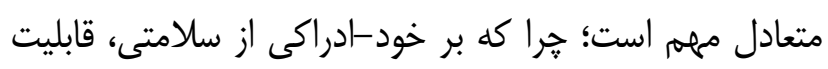
تفكر و فعاليت بدنى و در نتيجه كيفيت زندگى تأثير مى گتذارد

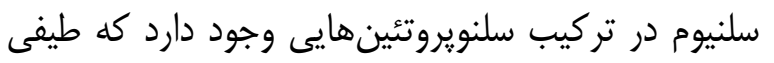

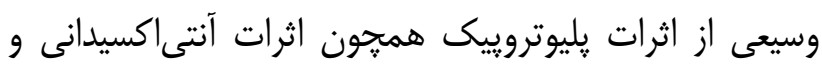

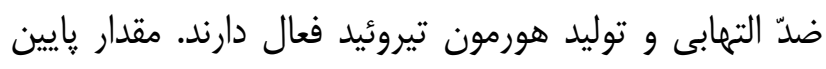

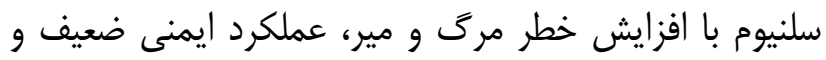
افت شناختى همراه است؛ در حالى كه مقدار طبيعى سلنيوم (يا

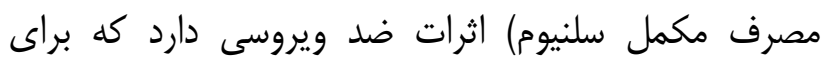

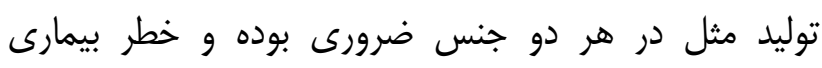

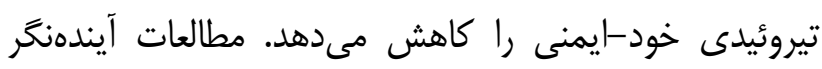

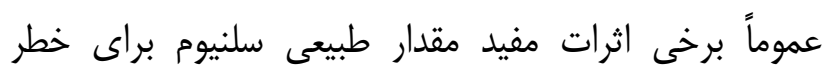

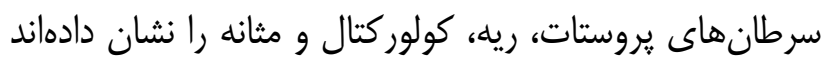

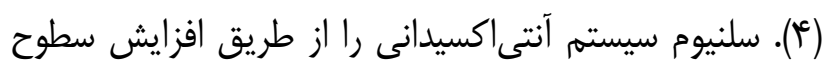

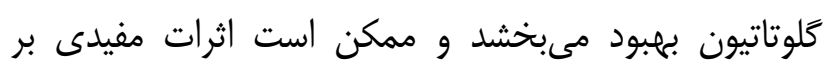


سال مشاركت منظم در تيمهاى فوتبال، بلهنوان مردان فعال

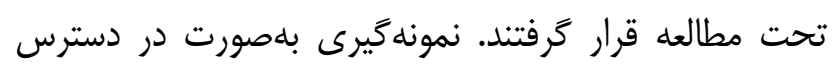

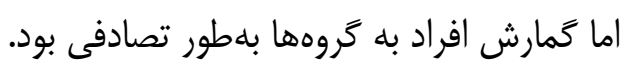

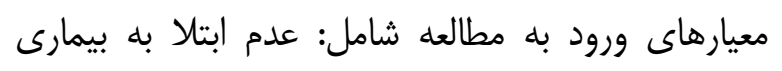
خاص (همجون بيمارىهاى سوختوسازى)، عدم مصرف دارو (همجون داروهاى ضدّ التهابى استروئيدى و غير استروئيدى)، عدم مصرف مكملهاى تغذيهاى (همجائون ويتامينهاى E و و عدم مصرف الكل و دخانيات در سه ماه قبل از شروع (C)

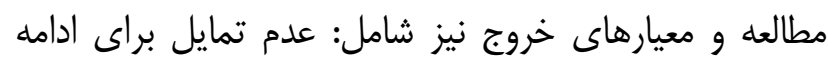

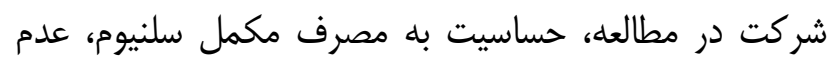

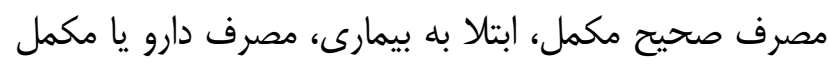

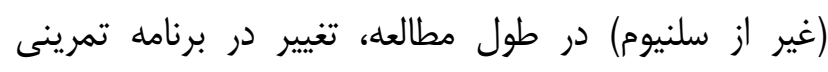

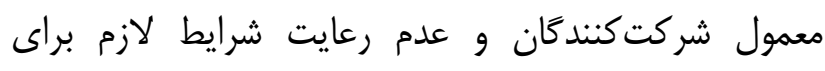

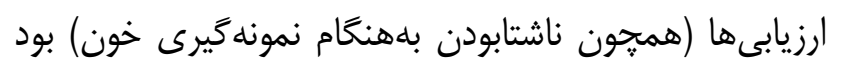

تعداد شركتكنندكان در شروع مطالعه r ب نفر بود كه

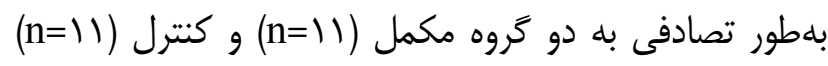

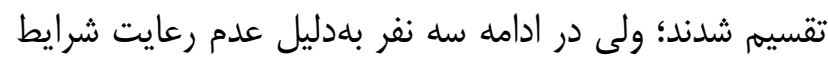

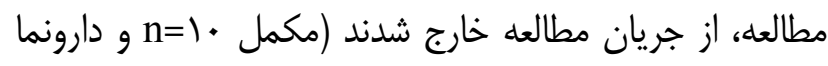

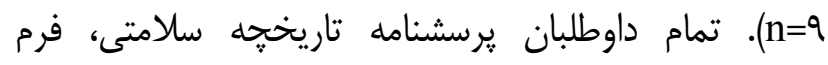

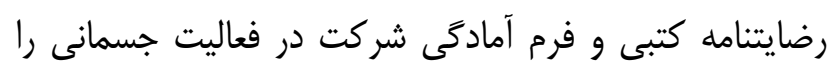

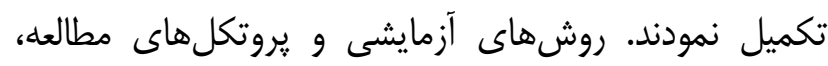
تحت نظارت شوراى يثوهشى دانشخاه آزاد اسلامى واحد سقز

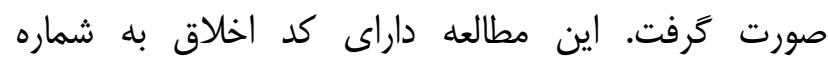
IR.SSRI.REC.1397.259 مكىباشد.

\section{روش اجرا}

قبل از شروع مصرف مكمل، ابتدا طى يك جلى جلسه

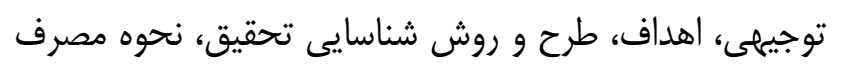

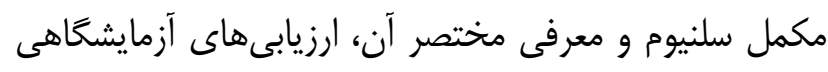
(مانند نمونه

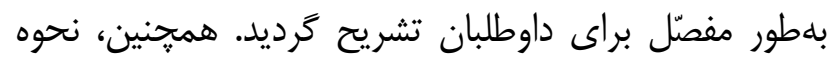
اجراى صحيح آزمون عملكرد قلبى-تنفسى (حداكثر اكسيثن
بهبود بخشد (•). از جمله عملكردهاى ضرورى سلنيوم در

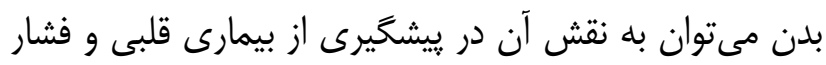

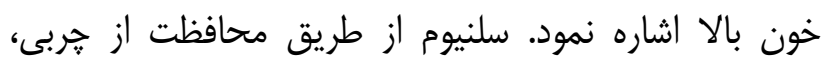

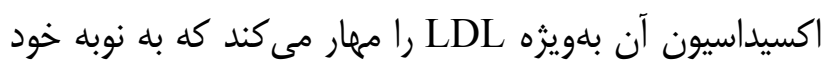
از رسوب كلسترول در ديواره شريان ييشخيرى مىنمايد (1I). در يك مطالعه نشان داده شد كه مصرف سلنيوم در بيماران ديابتى غلظت HDL را افزايش مى مدهد، اما تغييرى در در ديخر

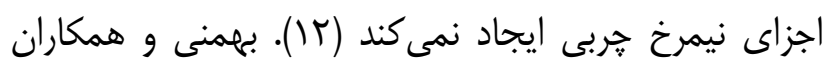

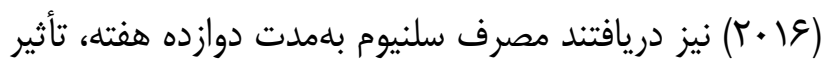

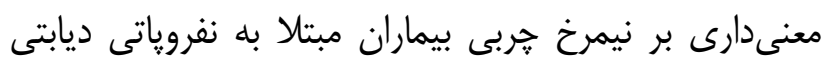

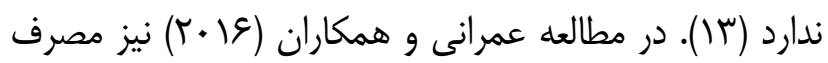

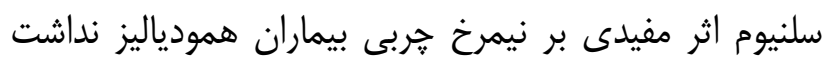

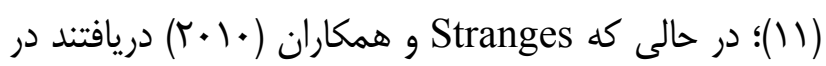
جمعيت بزرگسال انخليس، سلنيوم پياسمايى بالاتر با افزايش

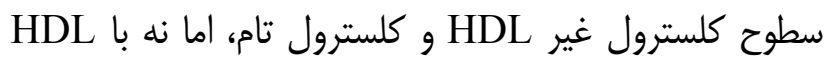
مرتبط است (9). تحقيقات اندكى در مورد اثرات مصرف سلنيوم بر نيمرخ جربى و عملكرد قلبى-تنفسى بلويزه در مردان جوان فعال

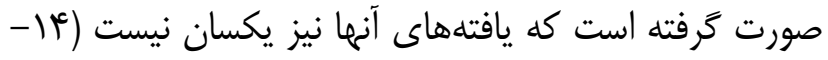

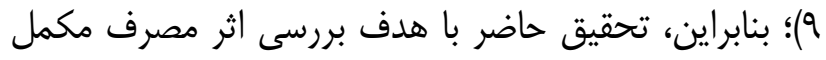

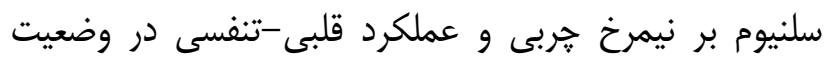
استراحت و متعاقب يك جلسه ورزش در مردان فعال صورت

\section{روش تحقيق}

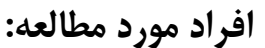

روش مطالعه حاضر از نوع نيمهجربى شامل گروههاى

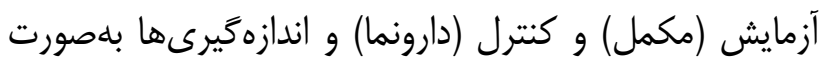
مكرر شامل ييشآزمون (قبل از مصرف مكمل)، يسآزتمل (آزمون

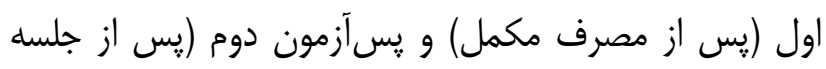

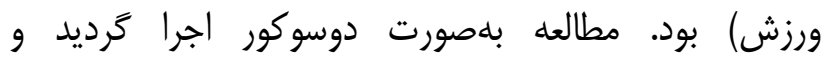
فوتباليستهاى مرد جوان شهرستان سقز با سابقه حداقل دو 
طول دوره مصرف مكمل، افراد هر دو گروه، برنامه تمرينى

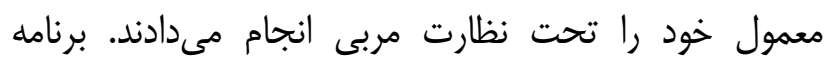

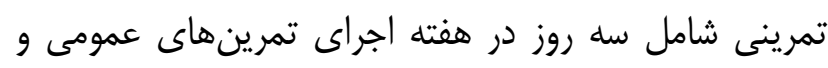

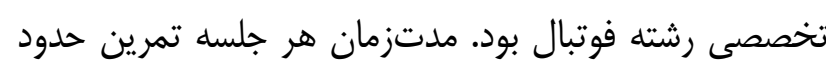

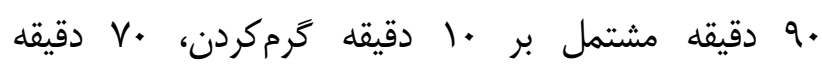
تمرينهاى ويزه فوتبال و • ا دقيقه سردكردن بود.

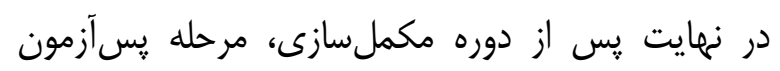

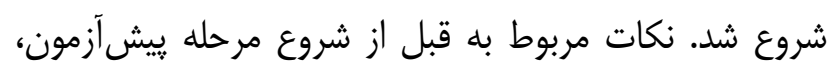

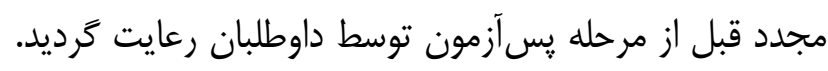

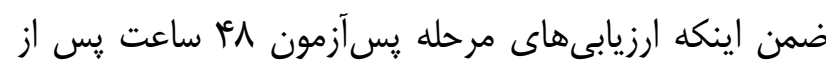

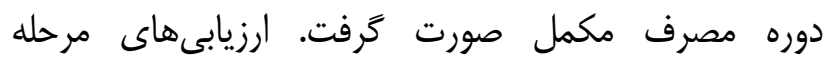

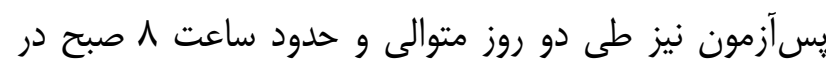

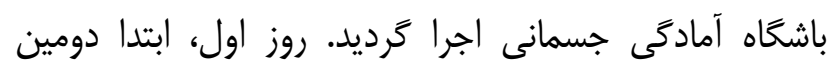

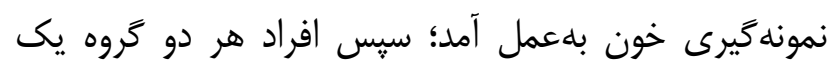

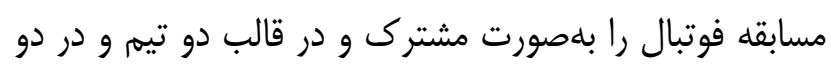
نيمه بهعنوان جلسه ورزش اجرا كردند. بلافاصله يس إن از اتمام

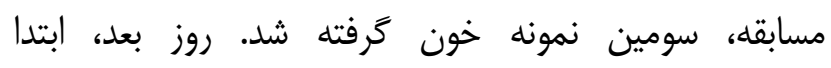

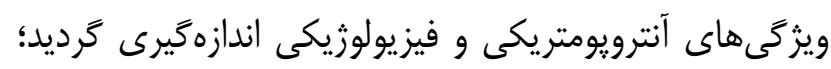

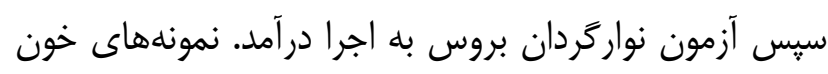

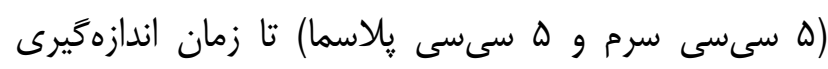

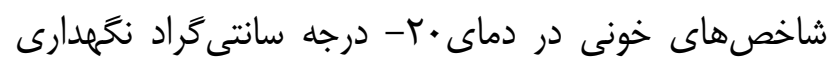

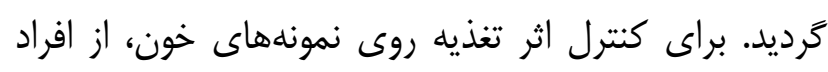

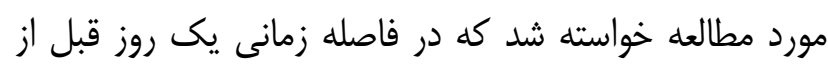

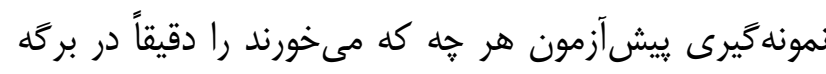

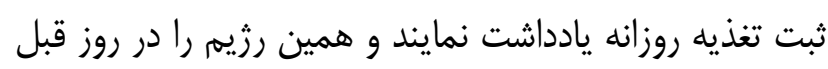
از نمونه گيرى يس آزمون، بلهور مجدد تكرار نمايند.

\section{ابزار تَردآورى دادهها}

وزن بدن با استفاده از دستخاه تجزيه و تحليل

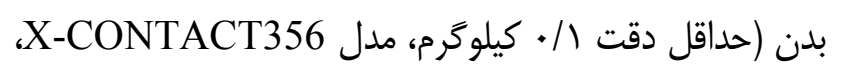

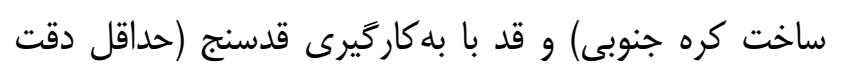

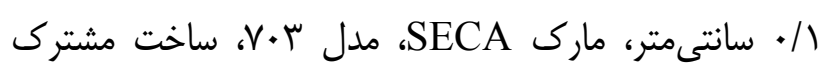

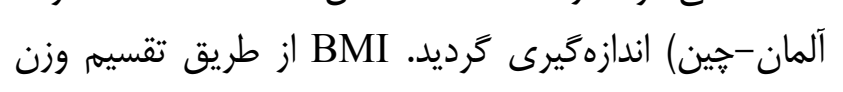

مصرفى) به داوطلبان آموزش داده شد و نكاتى كه افراد مورد

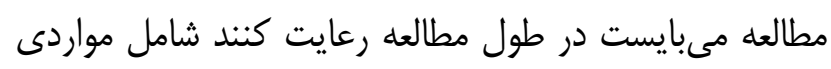
كه منجر به خروج داوطلبان از جريان تحقيق معى مَرديد و نيز

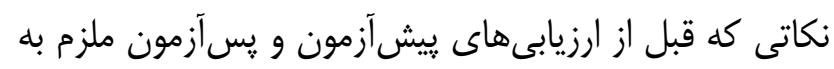

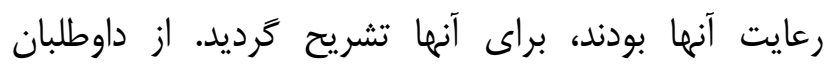
خواسته شد كه در طول دوره مطالعه، از هرگونه تغيير در رزيم إنمات

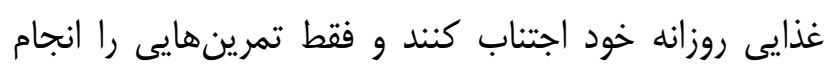
دهند كه جزء برنامه تمرينى معمول آنهاست.

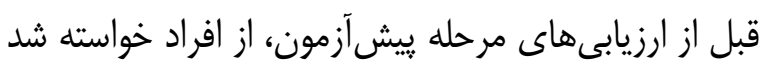

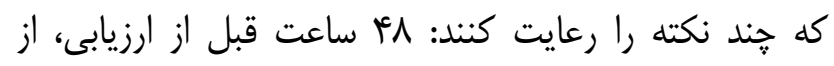

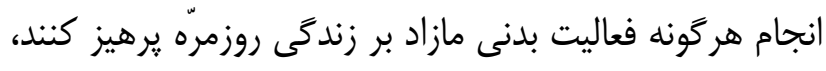

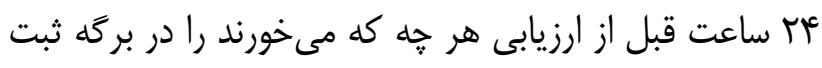

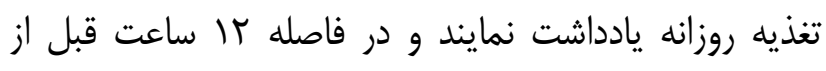

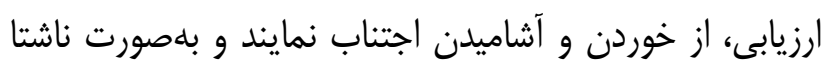
براى نمونهگيرى خون حضور يابند. ارزيابى آنهاى مرحله

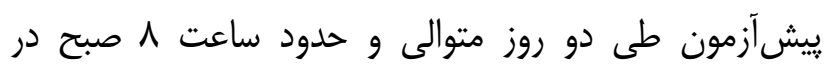

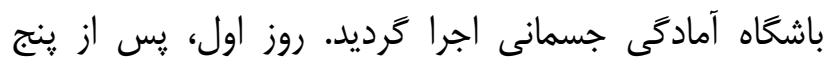

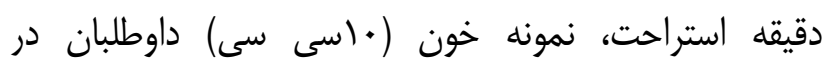

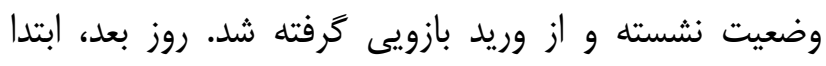

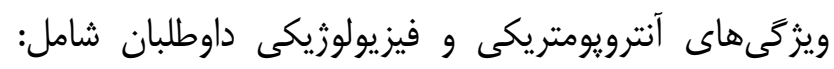

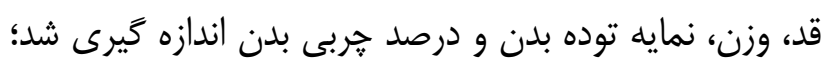

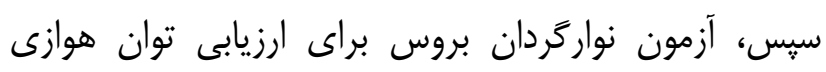

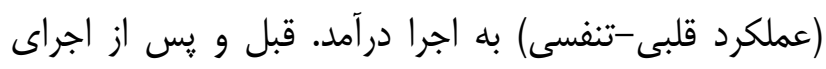

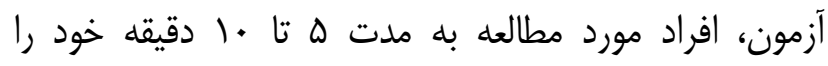
بلترتيب گرم و سرد مىنمودند.

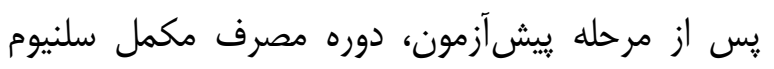

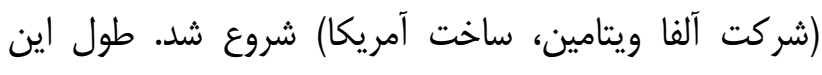

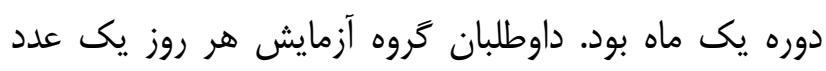

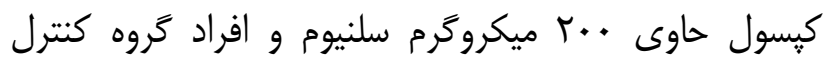
يك عدد كيسول همشكل و هماندازه حاوى نشاسته دريافت

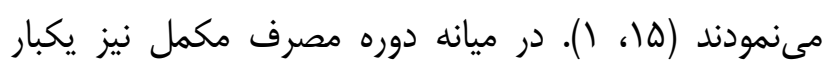

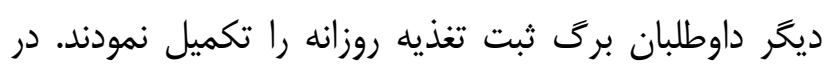


بلهنوان عامل درونگروهى در نظر گرفته شد. براى آزمون

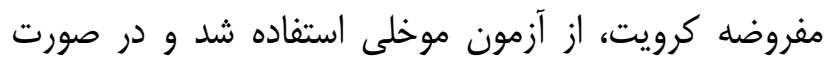

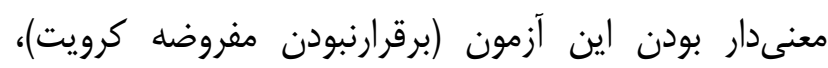

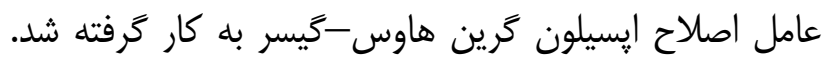

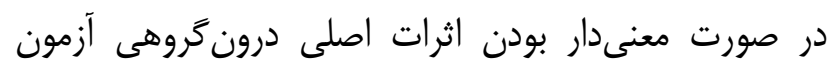

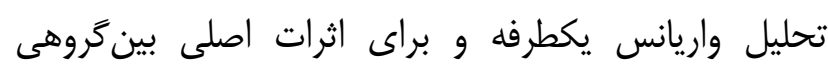

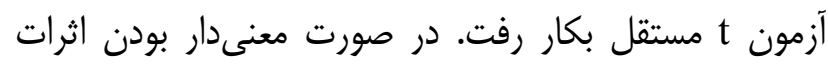

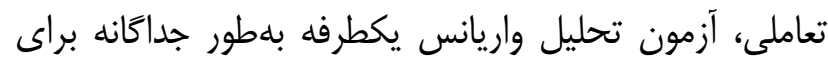

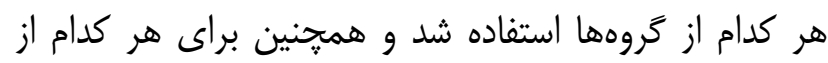

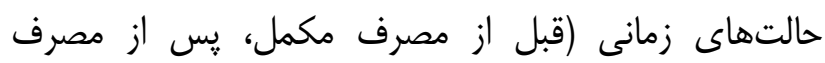

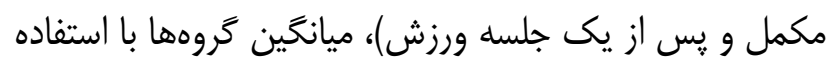

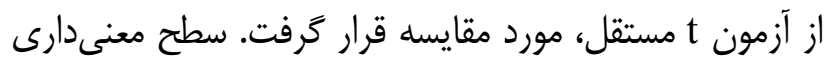

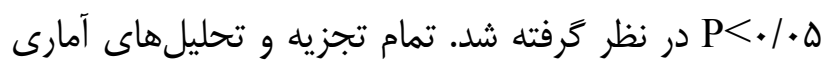

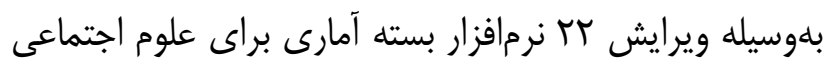
صورت كرفت. (SPSS)

\section{يافتهها}

ويثزى هاى عمومى افراد مورد مطالعه در جدول يك ارائه

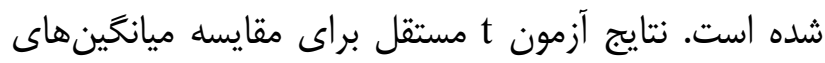

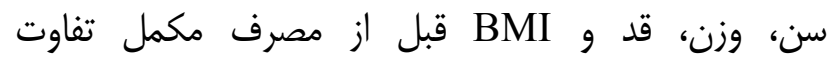

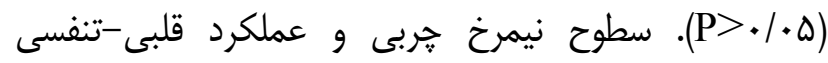

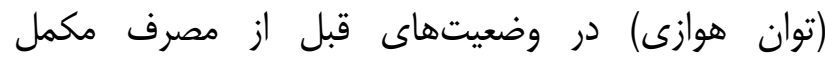
(ييشآزمون)، پس از مصرف) درف مكمل (يسآزمون) و متعاقب يك جلسه ورزش در جدول r گزارش شده است.

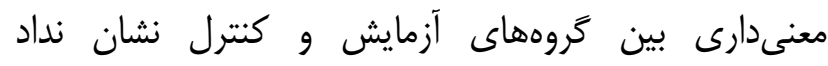

بلن (kg) بر مجذور قد (m²) محاسبه شد. درصد جربى بلن

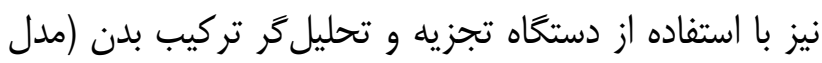
X-CONTACT356، ساخت كره جنوبى) تعيين گرديد.

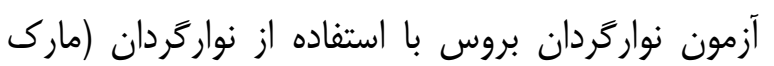

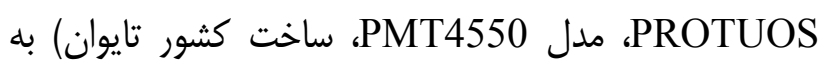
اجرا درآمد. در اين آزمون، فرد مورد مطالعه تا سر حدّ مدان

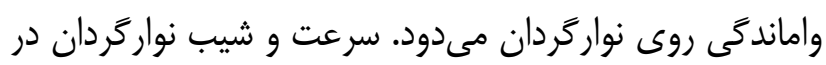

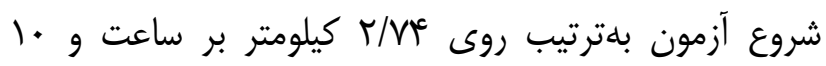

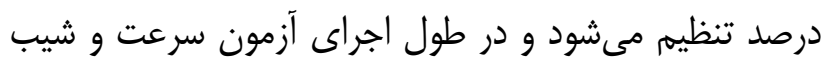

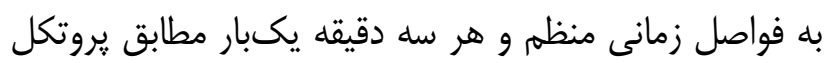
بروس افزوده مى

به محض اينكه فرد قادر به دويدن نباشد، متوقف مى شئ نرود.

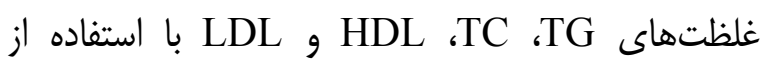
كيتهاى شركت يارسآزمون (ساخت ايران)، دستخاه

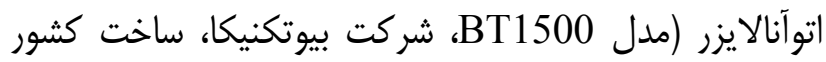

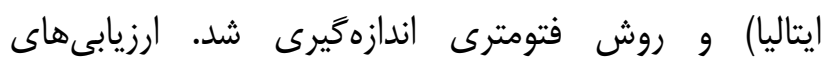
آزمايشگاهى در آزمايشگاه مركزى شهر سقز انجام كرفت.

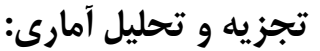

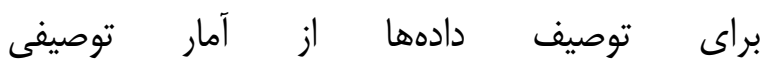

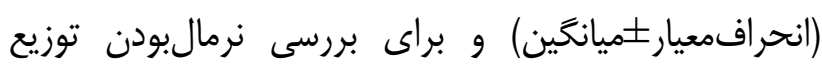

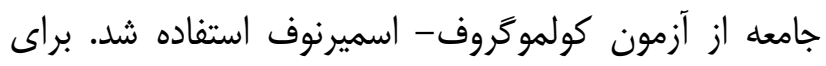

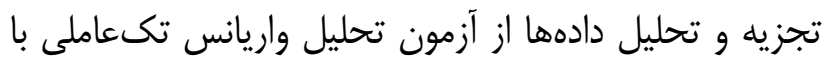

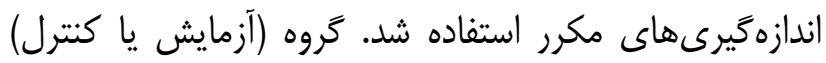
بلهنوان عامل بين

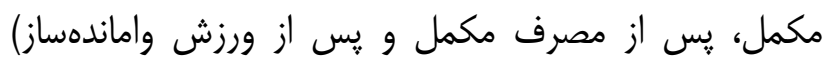
جدول ا- مقايسه ويثَّى هاى عمومى افراد مورد مطالعه (انحر افمعيار دميانكين)

\begin{tabular}{|c|c|c|c|}
\hline \multirow{2}{*}{ معنى دارى \# } & \multicolumn{2}{|c|}{ كروه } & \multirow{2}{*}{ 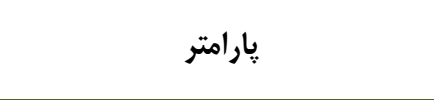 } \\
\hline & كنتر ل (n=q) & آزمايش (+n=1) & \\
\hline $.11 \cdot 9$ & $\mid \varepsilon / r \pm 1 / r$ & $\mid V / \Delta \pm I / \kappa^{e}$ & سن (سال) \\
\hline.$/ 411$ & $\Delta N / \Lambda \pm N / I$ & $s T / r \pm 1 \cdot / 4$ & وزن (كيلوگرم) \\
\hline . & $\mid V \kappa / q \pm \varphi / \varphi$ & $\mid \mathrm{VV} / \mathrm{I} \pm \mathrm{g} / \mathrm{\Delta}$ & قد (سانتىمتر) \\
\hline.$/ 9 T^{4}$ & $19 / \pi \pm r / r$ & $19 / \gamma \pm r / 4$ & شاخص توده بدن (كيلوَّرم بر متر مربع) \\
\hline
\end{tabular}

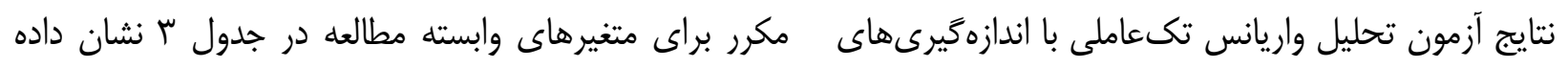




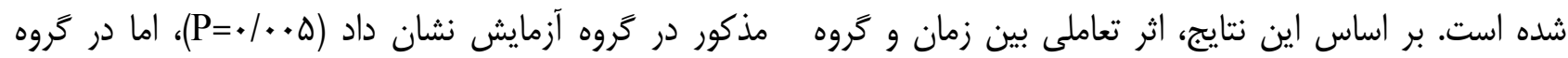

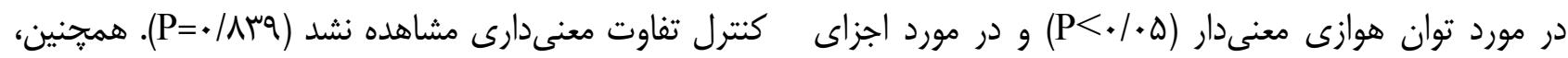

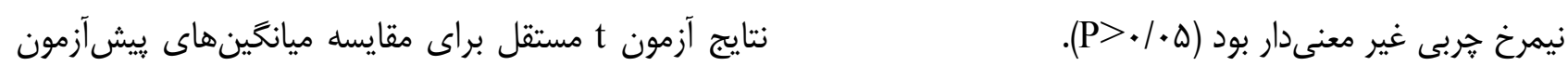

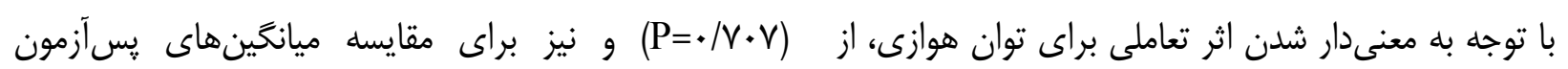

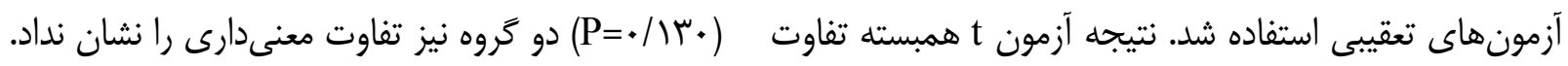

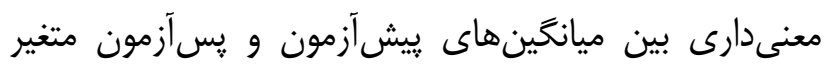

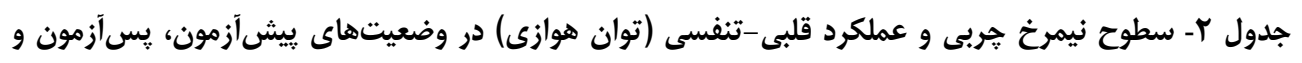

متعاقب يك جلسه ورزش (انحر اف معيار دميانتين)

\begin{tabular}{|c|c|c|c|}
\hline \multicolumn{2}{|c|}{ 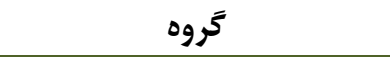 } & \multirow{2}{*}{ 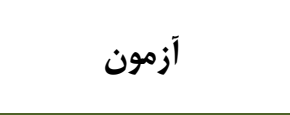 } & \multirow{2}{*}{ 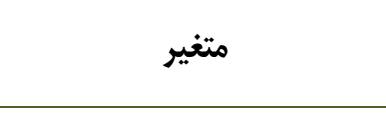 } \\
\hline 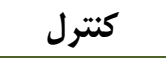 & 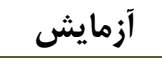 & & \\
\hline$|T V / V \pm T \Delta /|$ & $\mid r r / \Delta \pm r \varepsilon / \varepsilon$ & بيش آزمون & \multirow{3}{*}{ (ملسترَّر بر تام دسى ليتر) } \\
\hline $\mid r v / q \pm r \cdot / r$ & $\mid r \omega / \Lambda \pm \mu q / \kappa$ & 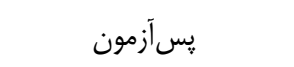 & \\
\hline $\mid F T / G \pm T r /$. & $|r| / q \pm r q / r$ & متعاقب يك جلسه ورزش & \\
\hline$v \cdot 1 \cdot \pm 19 / 1$ & $\Delta N / \Delta \pm I I / \Gamma$ & ي ييش آزمون & \multirow{3}{*}{ (ميلى گرىم بر دسى ليتر) } \\
\hline$V \Delta / I \pm r r / r$ & $s q / r \pm 18 / 1$ & 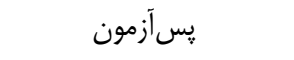 & \\
\hline$W / I \pm T V / T$ & $9 N / q \pm I V / T$ & متعاقب يك جلسه ورزش & \\
\hline$\kappa Y / \backslash \pm \digamma / \mathcal{F}$ & $19 / \Delta \pm 11 / 9$ & ييش آزمون & \multirow{3}{*}{ 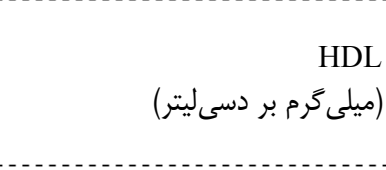 } \\
\hline$\kappa \Psi / \Lambda \pm \uparrow / \mathcal{F}$ & $\vdash q / \cdot \pm q / \Delta$ & 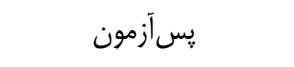 & \\
\hline$F \leftarrow / \Lambda \pm F / 1$ & $+q / x \pm 11 / x^{c}$ & متعاقب يك جلسه ورزش & \\
\hline$F V / T \pm 1 \cdot / r$ & $\lceil N / \Lambda \pm 1 \cdot / V$ & 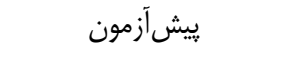 & \multirow{3}{*}{$\begin{array}{r}\text { LDL } \\
\text { (ميلى كرم بر دسىليتر) }\end{array}$} \\
\hline$\Delta \Psi / \& \pm I \cdot / \Lambda$ & $\Delta \cdot / r \pm 1 \cdot / r$ & 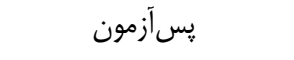 & \\
\hline$\Delta q / \Lambda \pm 1 \% / 4$ & $\Delta r /| \pm| Y / I$ & متعاقب يك جلسه ورزش & \\
\hline$r \mid / r \pm q / r$ & $\mathrm{rq} / \mathrm{v} \pm \mathrm{N} \cdot$ & 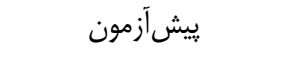 & توان هوازى (ميلىليتر به ازاى هر \\
\hline$F Y / \varepsilon \pm q / r$ & $\mathbb{F} V / V \pm V / F$ & 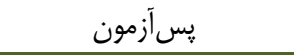 & كيلوَرم وزن بدن در دقيقه) \\
\hline
\end{tabular}

\# \# تجزيه و تحليل هاى آمارى با استفاده از آزمون تحليل واريانس تكىعاملى با اندازمكيرى هاى مكرر صورت كرفت.

جدول بـ- نتايج آزمون تحليل واريانس تكعاملى با اندازهَيرىهاى مكرر براى متغيرهاى وابسته

\begin{tabular}{|c|c|c|c|c|c|c|}
\hline \multicolumn{2}{|c|}{ اثر تعاملى } & \multicolumn{2}{|c|}{ اثر بين گَروهى } & \multicolumn{2}{|c|}{ اثر درون تروهى } & \multirow{2}{*}{ يارامتر } \\
\hline $\mathbf{P}$ & $\mathbf{F}$ & $\mathbf{P}$ & $\mathbf{F}$ & $\mathbf{P}$ & $\mathbf{F}$ & \\
\hline$\cdot / V w r$ & $\cdot / \mu \cdot \Lambda$ &.$/ 949$ & $.1+r^{c}$ & $.|| f \mid$ & $r / \cdot V \mu$ & كلسترول تام (ميلى گرم بر دسىليتر) \\
\hline$\cdot / V r^{2} \Delta$ & $\cdot / 4 \cdot \cdot$ & $\cdot / r \Delta \Lambda$ & I/rVt &.$/ 1 m \mathrm{r}$ & $r / 4 Q \Delta$ & ترى گليسريد (ميلى گرم بر دسىليتر) \\
\hline$\cdot / 4 \cdot 9$ & 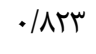 & $\cdot / \mathrm{Mr}$ & 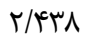 & $\cdot /$ eVte & . IATt & HDL \\
\hline 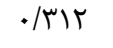 & $1 / 4 \cdot l^{r}$ & 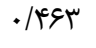 & • & .1 .91 & r/arq & LDL \\
\hline $.1 \cdot 18 *$ & $9 / 941$ & •/DTD & $\cdot / 4 \cdot 1$ & $\cdot 1 \cdot 1 \cdot:$ & N/PVT & توان هوازى (ميلىليتر بهازاى هر كيلوكرم وزن بدن در دقيقه) \\
\hline
\end{tabular}

مردان فعال بهبود مىبخشد، اما تأثيرى بر سطوح استراحتى و

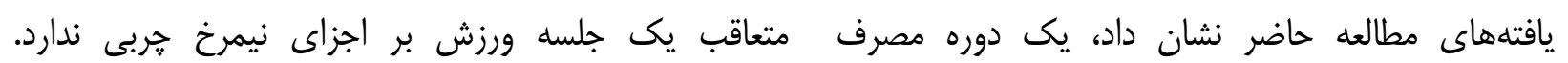

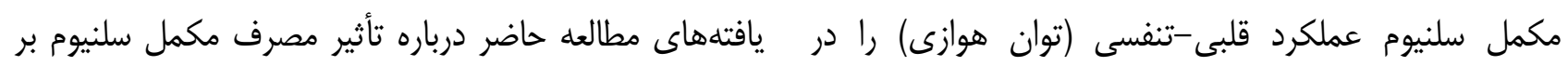


توجيه محتمل ديخرى براى اثر لييوزنيكِ در معرض

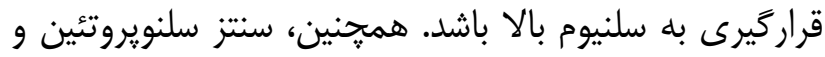

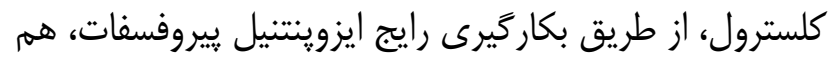

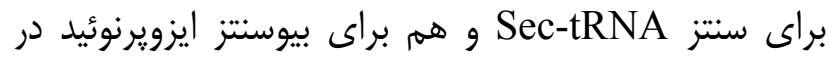
مسير مِوالونات، به يكديخر مرتبط هستند (9).

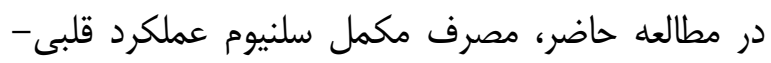

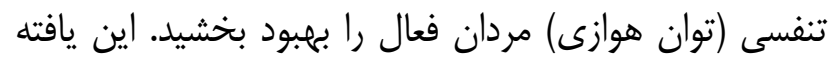

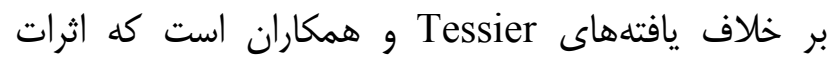
سلنيوم و تمرين بر سيستم كلوتاتيون و عملكرد هوازى را درا دمان

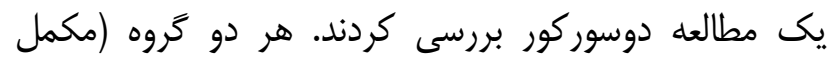

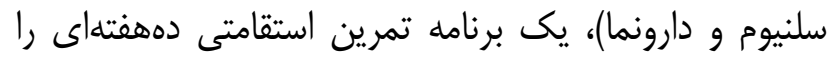

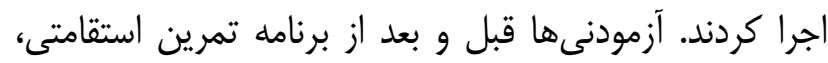
يك وهله تمرين واماندهساز طولانىمدت رأ را انجام دادند و قبل

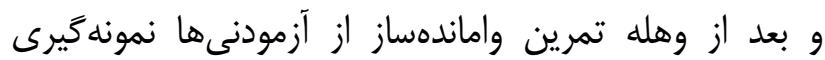
خون صورت گرفت. يافتههاى اين محققان بر نقش كلوتاتيون خون بلهنوان يك شاخص حساس فشار اكسايشى ناشى از

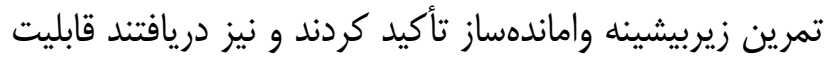

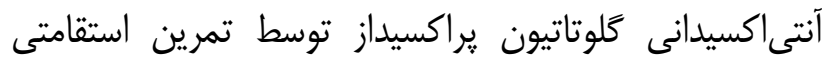

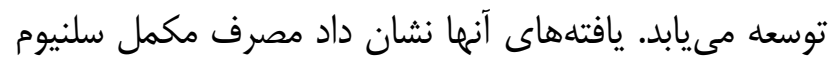
تأثيرى بر عملكرد جسمانى (VO2max) ندارد. سلنيوم جزئى ئى نئي

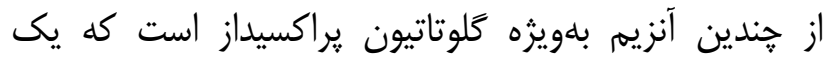

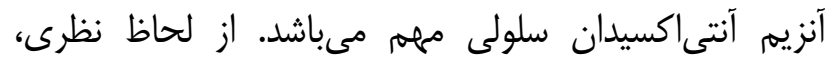
مصرف مكمل سلنيوم مىتواند از يراكسيداسيون غشاى سلول منال

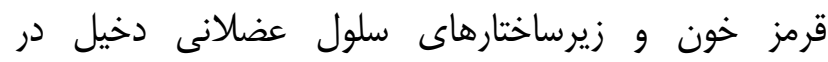

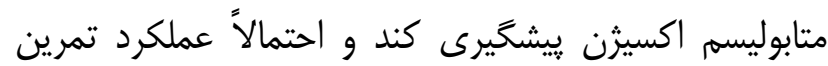

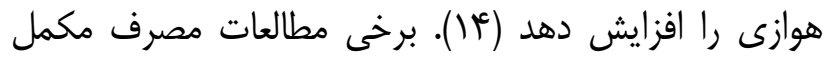

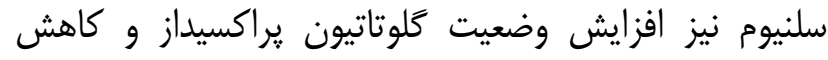
يراكسيداسيون خربى در تمرين هوازى طول كشنده را نشان دادهاند؛ با اين وجود عملكرد استقامتى واقعى در اين مطالعات

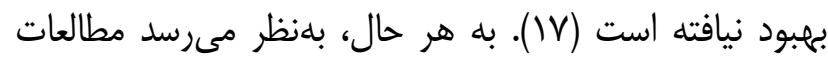

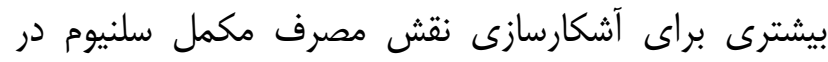
عملكرد ورزشى و بلويزه عملكرد قلبى-تنفسى مورد نياز
نيمرخ جربى، با يافتههاى تبريزى و همكاران، عمرانى و

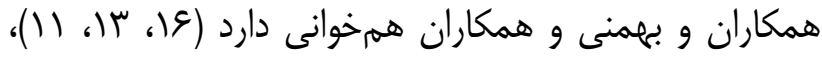

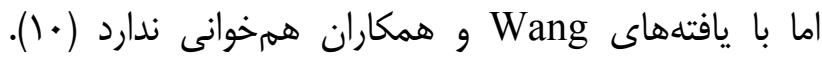
تبريزى و همكاران در يك مطالعه مرورى منظهم و فراتحليل

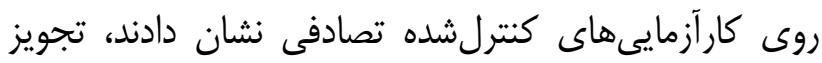

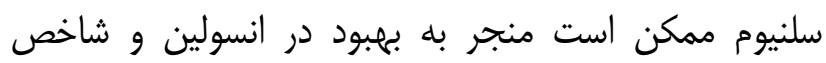

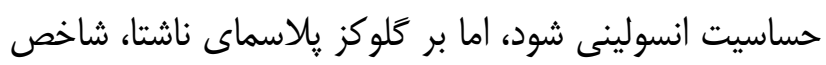

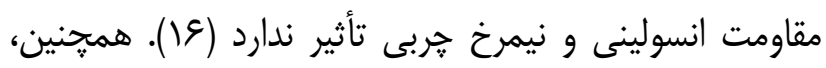

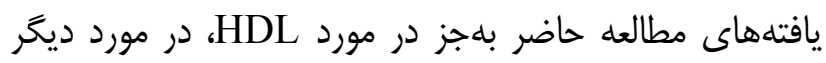

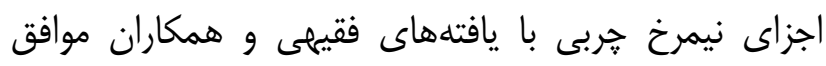

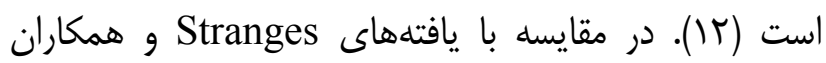

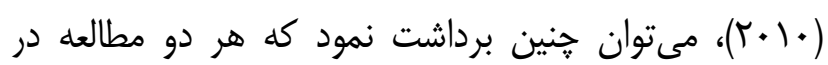
خصوص عدم ارتباط سلنيوم و HDL با يكديخر همراستا مىباشند، اما Stranges و همكاران به ريه رابطه مستقيم سطوح يلاسمايى سلنيوم و كلسترول تام اشاره كردهاند (9).

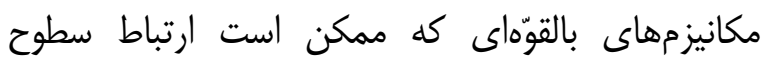

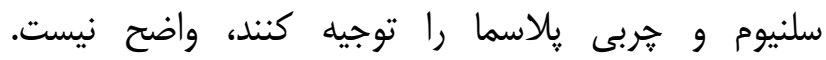

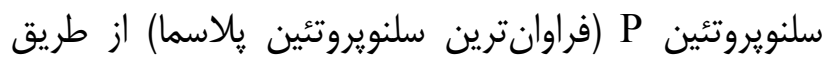
ي يرنده-r آيولييويروتئين E توسط مغنز مىشود؛ در حالى كه يك گيرنده آيولييويروتئين ديخر به نام

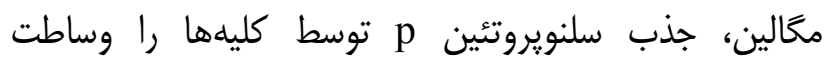

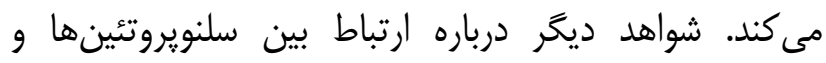
متابوليسم جربى از مدلهاى

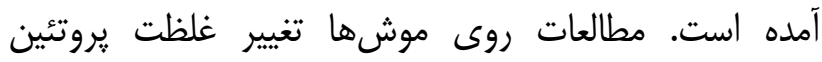
Apo E

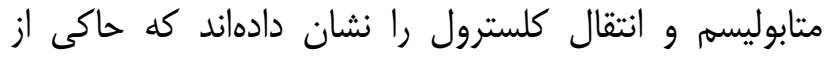
نقش سلنويروتئينها در تنظيه بيوسنتز لييويروتئين است؛

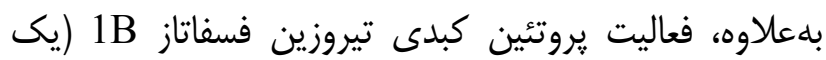

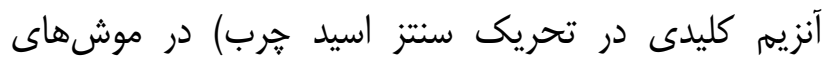

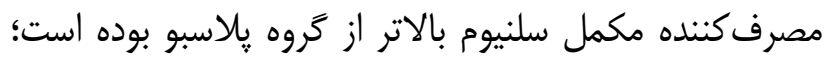
به نحوى كه موشهاى مصرفكننده مكمل سلنيوم داراى غلظتهاى ترى گليسريد كبدى بالاترى بودند كه مىتواند مهرى 
با مقدار مصرف روزانه +.r ميكروگرم بتواند بر اجزاى نيمرخ

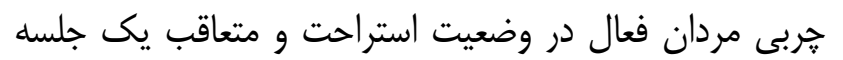
دلايل عدم همخوانى يافتههاى مطالعه ييشرو با

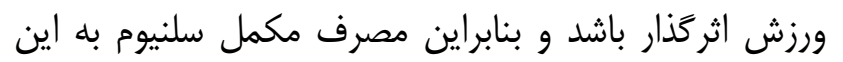

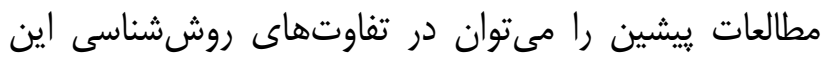

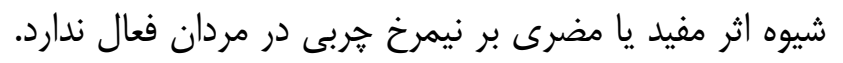
مطالعات همجون تفاوت در طول دوره مصرف مكمل و دوز

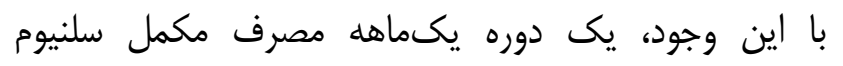

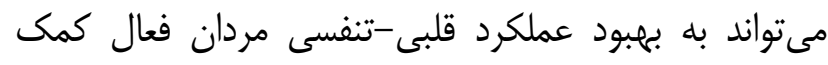

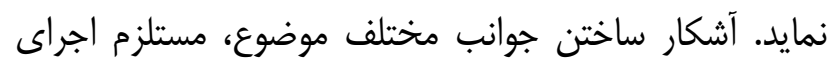
تحقيقات بيشتر است.

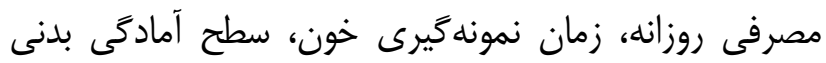

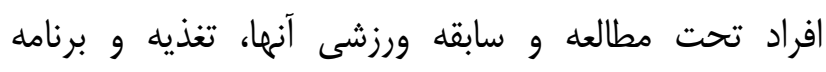

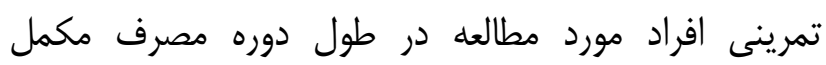

$$
\text { تحقيقات بيستر است }
$$

تقدير و تشكر

حجم نمونه مورد مطالعه، كنترل دقيق رزيم غذايى و

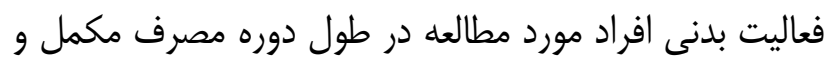
مقاله حاضر گزارشى برگرفته از پايان نامه كارشناسى ارشد

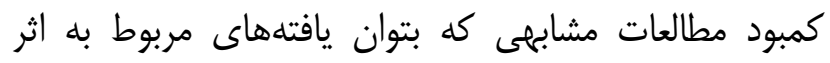

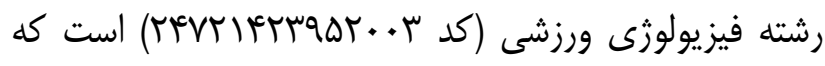

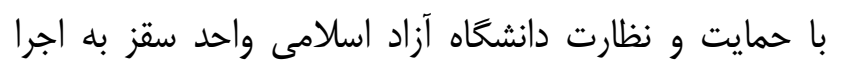

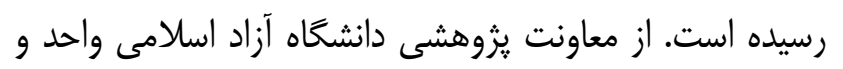

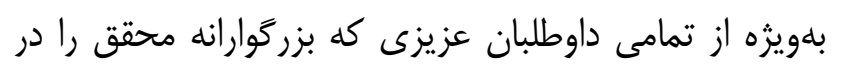
مصرف مكمل سلنيوم بر متغيرهاى وابسته مطالعه بلويزه عملكرد قلبى-تنفسى را با آنها مقايسه نمود، از ماز جمله

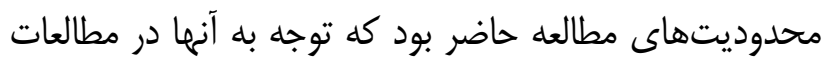
بعدى مى تواند به غناى تحقيقى در اين زمينه بيفزايد.

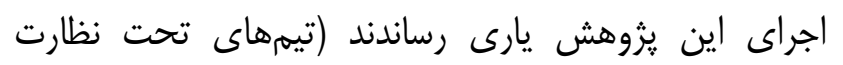

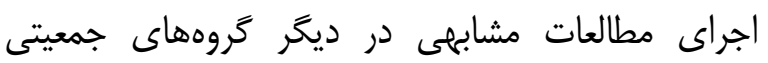
هيأت فوتبال شهرستان سقز)، صميمانه تشكر و و قدردانى

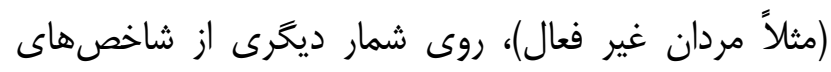

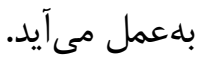

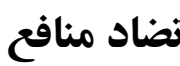

نويسندًان مقاله اعلام مىدارند كه هيجَّونه تضاد منافعى در يثوهش حاضر وجود ندارد.

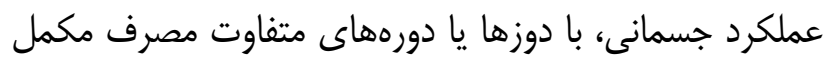

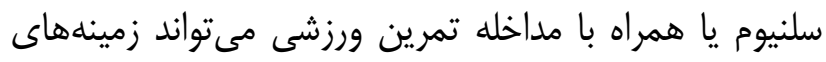

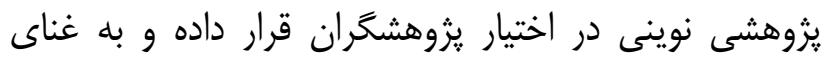
علمى در اين حيطه بيفزايد.

\section{نتيجل كيرى}

بلنظر نمىرسد مصرف مكمل سلنيوم بلمدت يكىماه و

1- Kim SS, Koo JH, Kwon IS, Oh YS, Lee SJ, Kim EJ, et al. Exercise training and selenium or a combined treatment ameliorates aberrant expression of glucose and lactate metabolic proteins in skeletal muscle in a rodent model of diabetes. Nutr Res Pract. 2011; 5(3): 205-13. doi: 10.4162/nrp.2011.5.3.205.

2- Yazdi MH, Masoudifar M, Varastehmoradi B, Mohammadi E, Kheradmand E, Homayouni S, et al. Effect of Oral Supplementation of Biogenic Selenium Nanoparticles on White Blood Cell Profile of BALB/c Mice and Mice Exposed to X-ray Radiation. Avicenna J Med Biotechnol. 2013; 5(3): 158-67.

3- González S, Huerta JM, Fernández S, Patterson AM, Lasheras C. Life-quality indicators in elderly people are influenced by selenium status. Aging Clin Exp Res. 2007; 19(1): 10-5.

4- Rayman MP. Selenium and human health. Lancet. 2012; 379(9822): 1256-68. doi: 10.1016/S0140-6736(11)61452-9. 
5- Hoffmann PR, Berry MJ. The influence of selenium on immune responses. Mol Nutr Food Res. 2008; 52(11): 127380. doi: 10.1002/mnfr.200700330

6- Kipp AP, Banning A, van Schothorst EM, Méplan C, Coort SL, Evelo CT, et al. Marginal selenium deficiency downregulates inflammation-related genes in splenic leukocytes of the mouse. J Nutr Biochem. 2012; 23(9): 1170-7. doi: 10.1016/j.jnutbio.2011.06.011.

7- Cohen HJ, Chovaniec ME, Mistretta D, Baker SS. Selenium repletion and glutathione peroxidase--differential effects on plasma and red blood cell enzyme activity. Am J Clin Nutr. 1985; 41(4): 735-47.

8- Williams MH. Dietary supplements and sports performance: minerals. J Int Soc Sports Nutr. 2005; 2(1): 43-9. doi: 10.1186/1550-2783-2-1-43

9- Stranges S, Laclaustra M, Ji C, Cappuccio FP, Navas-Acien A, Ordovas JM, et al. Higher selenium status is associated with adverse blood lipid profile in british adults. J Nutr. 2010; 140(1): 81-7. doi: 10.3945/jn.109.111252.

10- Wang N, Tan HY, Li S, Xu Y, Guo W, Feng Y. Supplementation of micronutrient selenium in metabolic diseases: Its role as an antioxidant. Oxid Med Cell Longev. 2017; 2017: 7478523. doi: 10.1155/2017/7478523.

11- Omrani H, Golmohamadi S, Pasdar Y, Jasemi K, Almasi A. Effect of selenium supplementation on lipid profile in hemodialysis patients. J Renal Inj Prev. 2016; 5(4): 179-82. doi: 10.15171/jrip.2016.38.

12- Faghihi T, Radfar M, Barmal M, Amini P, Qorbani M, Abdollahi M, et al. A randomized, placebo-controlled trial of selenium supplementation in patients with type 2 diabetes: effects on glucose homeostasis, oxidative stress, and lipid profile. Am J Ther. 2014; 21(6): 491-5. doi: 10.1097/MJT.0b013e318269175f.

13- Bahmani F, Kia M, Soleimani A, Asemi Z, Esmaillzadeh A. Effect of selenium supplementation on glycemic control and lipid profiles in patients with diabetic nephropathy. Biol Trace Elem Res. 2016; 172(2): 282-9. doi: 10.1007/s12011-015-0600-4.

14- Tessier F, Margaritis I, Richard MJ, Moynot C, Marconnet P. Selenium and training effects on the glutathione system and aerobic performance. Med Sci Sports Exerc. 1995; 27(3): 390-6.

15- Dolati Amirdizaj V, Saedmocheshi S. Muscle injury and oxidative stress following the use of selenium supplements and exhaustive aerobic exercise in young physically-active females. J Kermanshah Univ Med Sci. 2016; 20(1): 1-5. DOI: $10.22110 /$ jkums.v20i1.2659

16- Tabrizi R, Akbari M, Moosazadeh M, Lankarani KB, Heydari ST, Kolahdooz F, et al. The Effects of Selenium Supplementation on Glucose Metabolism and Lipid Profiles Among Patients with Metabolic Diseases: A Systematic Review and Meta-Analysis of Randomized Controlled Trials. Horm Metab Res. 2017; 49(11): 826-30. doi: 10.1055/s0043-119544.

17- Savory LA, Kerr CJ, Whiting P, Finer N, McEneny J, Ashton T. Selenium supplementation and exercise: effect on oxidant stress in overweight adults. Obesity (Silver Spring). 2012; 20(4): 794-801. doi: 10.1038/oby.2011.83. 